\begin{tabular}{|c|c|c|}
\hline & Int.J.Curr.Microbiol.App.Sci (2021) 10(10): 302-306 & \\
\hline EXCELLENT & $\begin{array}{l}\text { International Journal of Current Microbiology and Applied Sciences } \\
\text { ISSN: 2319-7706 Volume } 10 \text { Number } \mathbf{1 0}(\mathbf{2 0 2 1 )} \\
\text { Journal homepage: http://www.ijcmas.com }\end{array}$ & $\begin{array}{l}9 \\
39\end{array}$ \\
\hline PUBLISHERS & & www.ijemas.com \\
\hline
\end{tabular}

\title{
Development of Polyclonal Antibody-Based on Immunological Formats for Pathogen Detection in Groundnut Leaf Tissues
}

\author{
K. Chitra ${ }^{*}$, K. Dhananalakshmi ${ }^{2}$, N. Indra ${ }^{3}$, P. Mareeshwari ${ }^{3}$, \\ N. Ragupathi ${ }^{3}$ and V. Ambethgar ${ }^{1}$ \\ ${ }^{1}$ Tamil Nadu Rice Research Institute, Aduthurai, India \\ ${ }^{2}$ KVK, Vamban, India \\ ${ }^{3}$ Department of Plant Pathology, Tamil Nadu Agricultural University, Coimbatore, India \\ *Corresponding author
}

\section{A B S T R A C T}

Keywords

Detection of fungal pathogen-ELISAgroundnut leaf blight pathogen

\section{Article Info}

Accepted: 15 September 2021 Available Online: 10 October 2021
Immunological methods are highly useful to detect plant pathogens before symptom excrescence. Among the various immuno assay Enzyme Linked Immuno Sorbant Assay (ELISA) are well suited for detecting viral and fungal pathogens. The present investigation for the specific and early detection of groundnut leaf blight pathogen was standardized using polyclonal antiserum, the optimum dilution of antigen and antisera (antobody) was 1:1000 and 1:100 respectively with the titre value of 1:10. leaf blight infected groundnut plants could be detected 6 days before symptom expression. Prediction of infection well in advance help us to take remedial measures in time.

\section{Introduction}

Groundnut (Arachis hypogaea L.) is one of the important oilseed crops which is widely exploited for oil in the world. Groundnut is vulnerable to many diseases among them fungal disease incited by Alternaria alternata (Keissler) is the most destructive one which causes economic loss upto 40-50 per cent (Mathur and Sarbhoy, 1997). Early detection and diagnosis of the disease is highly imperative to adopt proper management strategy.
Fungal disease has been detected even before appearance of symptom using various immuno assays.

Application of immuno technology in plant pathology improves our knowledge of ecology and epidemiology of plant pathogens and also useful to screen the germplasm against the diseases.

Hence an attempt was made to develop early detection of pathogen by DAC ELISA using 
polyclonal antiserum.

\section{Materials and Methods}

Serology- antigens were prepared from healthy and inoculated plants. Purification was done by saturated ammonium sulphate fraction polyclonal antisera was raised in separate male white rabbit against mycelial antigen of $A$. alternata. Immunoglobulin antisera were purified (Chakraborty et al., 1995)

Detection of pathogen by Enzyme Linked Immunosorbent Assay (ELISA) Raising of Polyclonal antibodies

Pathogen was grown on PDA broth for 15 days. Freshly harvested mycelial mat was ground in $0.1 \mathrm{M}$ phosphate buffer $(\mathrm{pH} 7.0)$ and clarified at 12,000 rpm for $10 \mathrm{~min}$ at room temperature. One $\mathrm{ml}$ of the antigen was mixed with one $\mathrm{ml}$ of Freund's complete adjuvant, saline and emulsified in a cyclomixer.

The emulsion was given intramuscularly (4 months old New Zealand white rabbits weighing about $2.5 \mathrm{~kg}$ ) with sterile syringe for production of PAbs (polyclonal antibodies) against the pathogen antibody, after adjusting the protein content to $150 \mathrm{~g} \mathrm{ml}^{-1}$ (Bradford, 1976). Four injections were given at weekly intervals however, the fourth injection was an incomplete adjuvant. Bleeding was done 15 days after the last injection and the blood was transferred to sterile glass vials and allowed to stand in a slanting position until coagulated. The antiserum was transferred to sterile centrifuge tubes and the red blood cells were pelleted by centrifugation $\left(10,000 \mathrm{rpm}, 4^{\circ} \mathrm{C}\right.$, $10 \mathrm{~min}$ ) three times. The antiserum was stored at $4^{\circ} \mathrm{C}$ for further studies.

\section{Antigen preparation}

Leaf samples were collected from both healthy and infected plants. After washing, the samples were ground in $0.1 \mathrm{M}$ Carbonate buffer ( $\mathrm{pH}$ 9.6) in a sterile pestle and mortar at room temperature $\left(28 \pm 2^{\circ} \mathrm{C}\right)$ and clarified at $12,000 \mathrm{rpm}$ for $10 \mathrm{~min}$. at $4^{\circ} \mathrm{C}$. The supernatant was stored at $4^{\circ} \mathrm{C}$ for further studies.

\section{Direct Antigent Coating (DAC) ELISA}

DAC-ELISA method (Clark and Adams, 1977) was used for detection of A. alternata. Microtitre plates (Tarson, India) were first coated with $100 \mu \mathrm{l}$ of antigen for $2 \mathrm{~h}$ at $37^{\circ} \mathrm{C}$. The plates were washed three times with PBS$\mathrm{T}$. The primary antibodies diluted in PBS-T (1:1000) containing two per cent polyvinyl pyrrolidone and 0.2 per cent ovalbumin (PBSTPO) were added (100 $\mu$ l per well) separately. After incubation at $37^{\circ} \mathrm{C}(2 \mathrm{~h})$, the plates were washed using PBS-T. Alkaline phosphatase (ALP) conjugated goat anti-rabbit immunoglobulin (Bangalore Genei, India) (1:6000 with PBS-TPO) were added @ $100 \mu 1$ per well. The plates were incubated for $2 \mathrm{~h}$ at $37^{\circ} \mathrm{C}$. After washing in PBS-T, $100 \mu \mathrm{l}$ of 4nitrophenyl phosphate (SD Fine chemicals, India) dissolved in diethanolamine at $1 \mathrm{mg} \mathrm{ml}^{-}$ 1 (Sigma, USA) (pH 9.8) was added. The colour development (absorbance) was read at $405 \mathrm{~nm}$ with a microplate reader (Bio Rad Model 3550, USA). The reaction was terminated by adding $50 \mu \mathrm{l}$ of $3 \mathrm{M} \mathrm{NaOH}$ after incubation for half an hour at room temperature $\left(28 \pm 2^{\circ} \mathrm{C}\right)$.

\section{Results and Discussion}

Polyclonal antibodies raised against the fungal pathogen of groundnut leaf blight have been packaged in to ELISA formats for the quick and accurate detection of specific pathogen. Differences in ELISA reading between healthy and infected (artificially or naturally infected) groundnut leaf blight antigen indicates, extend of infection the antigen and 
antisera dilutions were 1: 100 and 1: 1000 respectively. Absorbance value for artificially inoculated leaf antigen preparation (1, 2, 3 and 4 day after inoculation) of all values were higher than their respective healthy leaf extracts in DACELISA format. Pathogens could be detected before the appearance of symptoms as early as 4 days after inoculation using DAC ELIS. Pathogen could be detected in infected leaf extract at concentration as low as $1 \mu \mathrm{g} / \mathrm{ml}$.

The titre value of the antiserum raised against pathogen was determined as described in
Table 1, using different dilutions of antigen and antiserum. The titre value was 1.231 , when the antibody dilution of 1:1000 and antigen dilution of 1:100 were used. Hence, the optimum dilution for antiserum and antigen was $1: 1000$ and $1: 100$ respectively (Table 1; Plate 1). The results of the experiments revealed that the presence of pathogen was detected on $4^{\text {th }}$ day after inoculation indicated that the disease can be detected 6 days before the symptom expression, where the natural symptom appears 10 days after artificial inoculation (Table 2; Plate 2).

Table.1 Determination of antiserum dilution

\begin{tabular}{|c|c|c|c|c|c|c|c|c|}
\hline \multirow{2}{*}{$\begin{array}{c}\text { Antigen } \\
\text { dilution }\end{array}$} & \multicolumn{7}{|c|}{ Antiserum dilution } \\
\cline { 2 - 10 } & $1: 50$ & $\mathbf{1 : 1 0 0}$ & $1: 200$ & $1: 500$ & $1: 1000$ & $1: 3000$ & Healthy & $\begin{array}{c}\text { Buffer } \\
\text { control }\end{array}$ \\
\hline $1: 50$ & 2.321 & 2.213 & 2.121 & 1.983 & 1.283 & 0.981 & 0.531 & 0.072 \\
\hline $1: 100$ & 2.212 & 2.184 & 2.083 & 1.897 & 1.181 & 1.011 & 0.611 & 0.061 \\
\hline $1: 200$ & 2.131 & 2.087 & 2.001 & 1.739 & 1.081 & 1.009 & 0.531 & 0.083 \\
\hline $1: 500$ & 1.921 & 0.991 & 0.931 & 0.921 & 0.889 & 0.811 & 0.489 & 0.091 \\
\hline $\mathbf{1 : 1 0 0 0}$ & 1.210 & $\mathbf{0 . 9 3 1}$ & 0.821 & 0.731 & 0.631 & 0.521 & 0.552 & 0.072 \\
\hline $1: 3000$ & 0.824 & 0.131 & 0.681 & 0.531 & 0.421 & 0.331 & 0.449 & 0.063 \\
\hline
\end{tabular}

Table.2 Detection of pathogen using ELISA at different days after inoculation

\begin{tabular}{|c|c|c|c|c|c|c|c|c|c|c|}
\hline \multirow{2}{*}{$\begin{array}{l}\text { Antigen } \\
\text { dilution }\end{array}$} & \multicolumn{10}{|c|}{ Antiserum dilution 1:1000 } \\
\hline & \multicolumn{10}{|c|}{ Infected samples (days after inoculation) } \\
\hline \multirow[t]{2}{*}{$1: 100$} & 0 & 1 & 2 & 3 & 4 & 5 & 6 & 7 & 8 & B \\
\hline & 0.418 & 0.521 & 0.693 & 0.983 & 1.231 & 1.421 & 1.692 & 1.824 & 2.032 & 0.078 \\
\hline \multicolumn{11}{|c|}{ Healthy samples (days) } \\
\hline \multirow{2}{*}{$1: 100$} & 0 & 1 & 2 & 3 & 4 & 5 & 6 & 7 & 8 & B \\
\hline & 0.418 & 0.423 & 0.451 & 0.438 & 0.512 & 0.531 & 0.549 & 0.561 & 0.581 & 0.078 \\
\hline
\end{tabular}


Plate.1 Determination of titre value of the antiserum

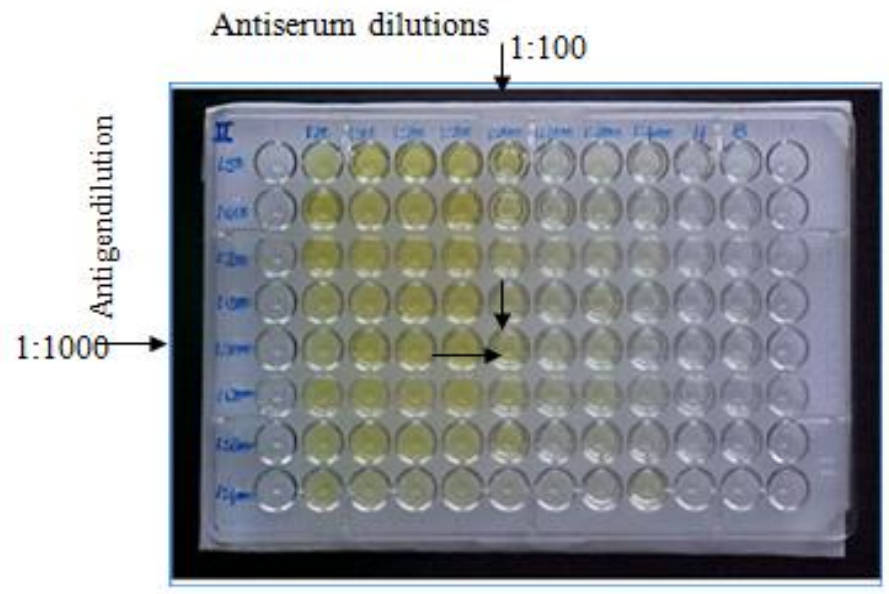

Plate.2 Detection of pathogen using ELISA at different days after inoculation

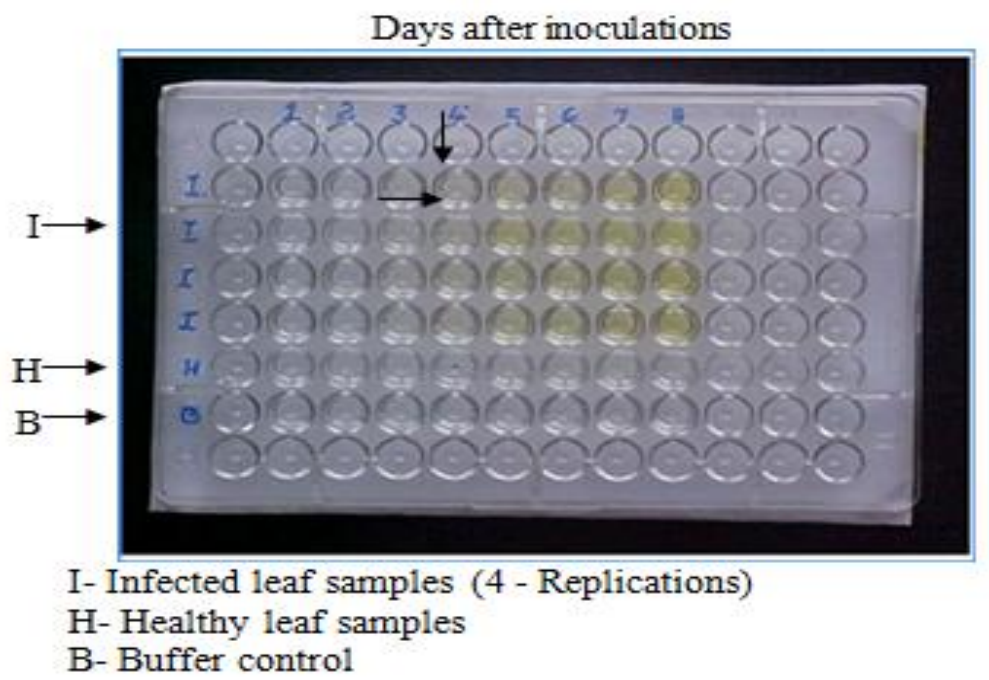

Similar results were reported by several workers. $P$. fragariae var. rabi was detected in root tissues of raspberry using a commercial multiwell assay kit from 4 days after inoculation (Olsson and Heiberg, 1997). Phytopthora infestans, causing potato late blight disease was detected by indirect ELISA before the appearance of first symptoms. Colletotrichum gloeosporioides infections in banana fruits were detected by ELISA even before the symptom expression (Sible, 2003).
Kandan (2003) also reported the detection of Ganoderma lucidum infection in coconut trees 75 days before symptom expression. Phomopsis spp. was detected in decayed soybean using polyclonal antibodies developed against Phomopsis spp. (Velichetti et al., 1993).

Disease prediction well in advance has also made it possible to take remedial measures in time. Fungal pathogens in general, are 
relatively easily diagnosed by the symptoms induced in infected plants and characteristics of spores and mycelium. In certain cases alternative methods like ELISA are required for their detection and identification. The use of this immuno assay will be helpful to detect the pathogen both $\mathrm{n}$ the seeds and plants and adopt suitable management strategies. More over the immuno assay is highly specific simple and large number of samples tested easily. To the best of our knowledge, this is the first diagnostic immuno assay for the early detection of leaf blight pathogen in groundnut.

\section{References}

Chakraborty B N., Basu P, Das, R, Saha, A, Chakraborty. U, (1995). Annals of Applied Biology 127, 11-21.

Bradford, M. M. (1976). A rapid and sensitive method for quantification of microgram quantities of protein utilizing the principle of protein dye binding. Ann. Biochem., 72: 248-254.

Clark, M. F., and Adams, A. N. (1977). Characteristics of the microplate method of enzyme linked immunosorbent assay for the detection of plant viruses.

J. Gen. Virol., 34: 475-483.

Kandan, A. 2003. Biotecnological approaches for early detection of Ganoderma diseases in plantation crops. Ph.D Thesis, Tamil Nadu Agricultural University, Coimbatore, India. p. 125

Mathur, S. B. and Sarbhoy, A. K. (1997). Physiological studies on Alternaria alternata from sugar beet. Indian Phytopath., 30: 384-387.

Olsson, C. H. B. and Heiberg, N. (1997). Sensitivity of the ELISA test to detect Phtophthora frgariae var. rubi in raspberry roots. J. Phtopathol., 145: 285-288.

Sible G. V. (2003). Biotechnology based approaches for the early detection and management of post harvest anthracnose in banana. Ph. D. Thesis, Tamil Nadu Agricultural University, Coimbatore, India. p. 135

Velicheti, R. K., Lamison, C., Brill, L. M. and Sinclair, J. B. (1993). Immuno detection of Phomopsis species in asymptomatic soybean plants. Plant Dis., 77: 70-73.

\section{How to cite this article:}

Chitra, K., K. Dhananalakshmi, N. Indra, P. Mareeshwari, N. Ragupathi and Ambethgar, V. 2021. Development of Polyclonal Antibody-Based on Immunological Formats for Pathogen Detection in Groundnut Leaf Tissues. Int.J.Curr.Microbiol.App.Sci. 10(10): 302-306. doi: https://doi.org/10.20546/ijcmas.2021.1010.037 